\title{
Pengaruh Model Discovery Learning Berbantuan Media Lingkungan Alam Sekitar terhadap Hasil Belajar IPA
}

\author{
Ni Ketut Intan Bahari*, I Wayan Darsana², DB. Kt. Ngr. Semara Putra ${ }^{3}$
}

Jurusan Pendidikan Guru Sekolah Dasar (PGSD), Universitas Pendidikan Ganesha, Singaraja, Indonesia.

\author{
A R T I C L E I N F O \\ Article history: \\ Received 20 February 2018 \\ Received in revised form \\ 6 March 2018 \\ Accepted 19 April 2018 \\ Available online 26 May \\ 2018 \\ Kata Kunci: \\ discovery learning, media \\ lingkungan alam sekitar, \\ IPA. \\ Keywords: \\ discovery learning model, \\ natural scien \\ media,outcomes of scien \\ studies learing
}

\begin{abstract}
A B S T R A K
Penelitian ini bertujuan untuk mengetahui perbedaan yang signifikan hasil belajar IPA siswa yang dibelajarkan melalui model Discovery Learning Berbantuan Media Lingkungan Alam Sekitardan siswa yang dibelajarkan melalui pembelajaran konvensional pada kelas $\mathrm{V}$ SD Gugus 5 Blahbatuh Tahun Ajaran 2016/2017. Penelitian ini merupakan eksperimen semu dengandesain penelitian Nonequivalent Control Group Desaign. Populasi dalam penelitian ini adalah seluruh siswa kelas V SD Gugus 5 Blahbatuh yang berjumlah 131 orang. Penentuan sampel menggunakan teknik random sampling diperoleh kelas V SD Negeri 4 Pering dan SD Negeri 2 Pering. Penentuan kelompok kontrol maupun kelompok eksperimen dilakukan dengan pengundian. Berdasarkan hasil penelitian, nilai rata-rata hasil belajar IPA siswa pada kelompok eksperimen yaitu $\bar{X}=80,00$ dan pada kelompok kontrol yaitu $\bar{X}=70,30$. Hasil uji hipotesis diperoleh $t_{\text {hitung }}=$ 3,666 dan pada taraf signifikansi $5 \%$ dengan $d k=32+30-2=60$, maka diperoleh harga $t_{\text {tabel }}=2,000$. Hasil $t_{\text {hitung }}=3,666>t_{\text {tabel }}\left(\alpha_{=0,05,60)}=2,000\right.$, maka $\mathrm{H}_{0}$ ditolak dan $\mathrm{H}_{\mathrm{a}}$ diterima. Dapat disimpulkan bahwa terdapat perbedaan yang signifikan hasil belajar IPA antara kelompok siswa yang dibelajarkan melalui model Discovery Learning BerbantuanMedia Lingkungan Alam Sekitar dan kelompok siswa yang dibelajarkan melalui
\end{abstract} pembelajaran konvensional pada siswa kelas V SD Gugus 5 Blahbatuh Tahun Ajaran 2016/2017. Dengan demikian, dapat disimpulkan bahwa penggunaan model Discovery Learning Berbantuan Media Lingkungan Alam Sekitarberpengaruh terhadap hasil belajar IPA siswa kelas V SD Gugus 5 Blahbatuh Tahun Ajaran 2016/2017.

\section{A B S T R A C T}

The research aims to determining students learning outcome of natural science at class five. In which students are being educated by discovery learning model natural rocks environmental around of students that is learned with conventional leaning program for student class five at elementary school Gugus 5 Blahbatuh. This reseacarching is constitute in experiment researching of Nonequivalent Control Grup Desain. The population 131 students in five grade of elementary school in Gugus 5 Blahbatuh. This sampel was chosen by using randomsampling technique. there two class asresearching sample in which is SD Negeri 4 Pering as experiment group with 32 students and SD Negeri 2 Pering as group control with 30 students, the data collector by using objective test with multiple choice and then analysis, the average of students learning outcomes at natural science for experiment class is 80,00 and at class control 70,30 , the after do to hypothesis examination it gated arithmetic 3,666 in significant $5 \%$ with $\mathrm{dk}=32+30-2=60$ prices ttable 2,000 so it can be said arithmetic $=3.666>$ ttable $=2,000(a=0,05,60)=2,000$. Then $\mathrm{HO}$ rejected and $\mathrm{Ha}$ accepted, this mean the stream of researching that show the indication there are differences in learning outcome at natural science class between experiment class and control class, Therefore we can conclude that used discovery learning model natural aound rock environment media auoud of student learning outcomes for student area effecting of student learning outcomes for students of natural scien at class five in Gugus 5 Blahbatuh in academic years 2016/2017.

Copyright (C) Universitas Pendidikan Ganesha. All rights reserved. 


\section{Pendahuluan}

Pendidikan memiliki peran penting dalam menentukan kemajuan suatu bangsa. Melalui pendidikan seseorang dapat mengubah pola pikirnya. Pendidikan memberikan kemungkinan kepada siswa untuk memperoleh kesempatan, harapan, dan pengetahuan agar dapat hidup secara lebih baik. Pendidikan dapat menjadi kekuatan untuk melakukan perubahan menuju kondisi yang lebih baik. Pendidikan baik dari segi kurikulum, metode, model pembelajaran, serta teori bersifat dinamis yang sewaktu-waktu dapat berubah sesuai dengan situasi dan kondisi yang terjadi dimasyarakat.

Teori-teori pembelajaran yang diterapkan di sekolah-sekolah tidak selamanya bisa diterima sebagai upaya dalam peningkatan hasil belajar siswa. Dengan demikian, guru diharapkan kreatif dalam menerapkan berbagai model pembelajaran yang inovatif guna meningkatkan motivasi dan kreativitas siswa sehingga hasil belajar meningkat. Inti dari suatu pendidikan adalah proses pembelajaran.

Pembelajaran adalah suatu sistem yang terdiri dari berbagai komponen. Komponen utama sebuah pembelajaran adalah peserta didik yang berkedudukan sebagai subjek belajar dan guru sebagai fasilitator pembelajaran. Guru sebagai fasilitator pembelajaran berperan dalam kegiatan pembelajaran untuk menciptakan suasana belajar yang menyenangkan. Suasana yang menyenangkan dalam proses pembelajaran berdampak positif dalam pencapaian hasil belajar.Melalui hasil belajar dapat dilihat keberhasilan siswa dalam memahami suatu materi pelajaran.Diharapkan dalam pembelajaran siswa memperoleh hasil belajar yang tinggi pada setiap mata pelajaran begitu juga pada mata pelajaran IPA.

IPA merupakan salah satu mapelajaran di Sekolah Dasar yang memberikan kesempatan kepada anak berpikir kritis dan objektif. Mata pelajaran ini mempunyai nilai-nilai pendidikan yaitu mempunyai potensi yang dapat membentuk kepribadian anak secara ke-seluruhan Samatowa (2011:4). Ilmu Pengetahuan Alam (IPA) berhubungan cara mencari tahu tentang alam secara sistematis, sehingga IPA bukan hanya penguasaan kumpulan pengetahuan yang berupa fakta-fakta, konsep-konsep, atau prinsipprinsip saja tetapi juga merupakan suatu penemuan (Sapriati dkk,2014: 8.22).

Begitu pentingnya peranan IPA seperti yang diuraikan di atas, hendaknya IPA dapat dikuasai dan menjadi mata pelajaran yang menyenangkan bagi siswa. Pembelajaran IPA, di Sekolah Dasar dilakukan dengan penyelidikan sederhana dan bukan hapalan terhadap kumpulan konsep IPA. Wisudawati dan Sulistyowati (2015:16) menyatakan bahwa materi-materi dalam IPA mempelajari fenomena-fenomena alam dan memerlukan penalaran lebih oleh peserta didik.

Namun demikian, tidak dapat dipung-kiri mata pelajaran IPA selama ini dianggap sebagai mata pelajaran yang sulit dan membosankan. Kondisi ini mengakibatkan mata pelajaran IPA tidak disenangi, tidak diperdulikan bahkan diabaikan. Hal ini tentunya menimbulkan masalah dimana terjadi kesenjangan yang cukup besar antara apa yang diharapkan dari pembelajaran IPA dengan yang terjadi dilapangan. IPA di satu sisi mempunyai peranan penting dalam kehidupan sehari-hari, melatih anak berpikir kritis dan objektif, serta dapat membentuk kepribadian anak. Di sisi lain banyak siswa yang tidak menyenangi mata pelajaran IPA. Kondisi ini berdampak terhadap perolehan hasil belajar siswa. Begitu juga yang terjadi pada Gugus 5 Blahbatuh, dimana pembelajaran IPA menjadi keluhan para guru karena hasil belajar IPA siswa masih kurang optimal.

Berdasarkan hasil observasi yang dilakukan terhadap pembelajaran di SD Gugus 5 Blahbatuh, Kecamatan Blahbatuh Kabupaten Gianyar pada tanggal 22 Desember 2016 dan 7 Januari 2017 bahwa proses pembelajaran yang dilaksanakan pada masing-masing sekolah bersangkutan didominasi oleh keterlibatan guru dalam proses pembelajaran. Pelaksanaan pembelajaran IPA yang dilakukan adalah: (1) pembelajaran diawali penjelasan singkat terkait materi oleh guru dan terpaku pada buku, siswa mendengarkan dan mencatat, (2) dilanjutkan dengan pemberian contoh soal dan (3) diakhiri dengan evaluasi. Siswa yang pintar lebih banyak mendominasi jawaban dari pertanyaan guru sementara siswa yang lain lebih senang bermain dan berbicara dengan teman sebangkunya dibandingkan mendengarkan penjelasan guru.

Berdasarkan dengan hal di atas pembelajaran tersebut masih menerapkan pembelajaran konvensional.Dewasa ini telah dilakukan berbagai upaya dalam perbaikan serta peningkatan mutu pembelajaran IPA di sekolah. Berbagai model pembelajaran bisa diterapkan oleh guru, salah satunya model discovery learning. Model discovery learning yang dipadukan dengan media lingkungan alam sekitar bisa menjadi suatu alternatif dalam upaya peningkatan hasil belajar siswa. Menurut Putrayasa (2014) model pembelajaran discovery learning memiliki beberapa kelebihan, yaitu: 1) menambah pengalaman siswa dalam belajar, 2) memberikan kesempatan kepada siswa untuk lebih dekat lagi dengan sumber pengetahuan selain buku, 3) menggali kreatifitas siswa, 4) mampu meningkatkan rasa percaya diri pada siswa, dan 5) meningkatkan kerja sama antar siswa.

Menurut Supriyanto (2014) discovery learning adalah metode mengajar yang mengatur pengajaran sedemikian rupa sehingga anak memperoleh pengetahuan yang sebelumnya belum 
diketahuinya tanpa pemberitahuan langsung sebagian atau seluruhnya ditemukan sendiri. Agus $\mathrm{N}$. Cahyo (2012:101) me-nyatakan pembelajaran discovery ialah suatu pembelajaran yang melibatkan siswa dalam proses kegiatan mental melalui tukar pendapat, dengan diskusi, membaca sendiri, dan mencoba sendiri, agar anak dapat belajar sendiri. Siswa cukup diberikan konsep utama, untuk selanjutnya siswa dibimbing agar dapat menemukan sendiri sampai akhirnya dapat mengordinasikan konsep tersebut secara utuh. Oleh karena permasalahan yang dialami siswa berkaitan dalam mata pelajaran IPA, dimana identik tentang alam sekitar, maka model discovery learning ini akan lebih baik jika dipadukan dengan media lingkungan alam sekitar. Menurut Fitri (2015) model Discovery Learnin merupkan salah satu model pembelajaran yang dapat meningkatkan hasil belajar siswa melalui penalaran, menemukan sesuatu untuk dirinya dalam memahami struktur ide-ide kunci. pembelajaran Dengan demikian, siswa akan belajar menemukan sendiri, mengordinasikan dan menyimpulkan pemahamannya terkait mata pelajaran IPA sehingga penge-tahuan tersebut akan lama tersimpan dalam ingatan siswa. Hal ini didukung dengan kondisi dan lokasi dari sekolah dasar yang terdapat di Gugus 5 Blahbatuh yang dominan terletak di daerah pedesaan dengan wilayah yang masih alami dengan kawasan hijau masih tersedia. Sehingga sangat memungkinkan untuk memanfaatkan lingkungan alam sekitar sebagai media dalampembelajaran khususnya dalam pembelajaran IPA.

Berdasarkan paparan di atas, maka menarik untuk melakukan sebuah pene-litian tentang "Pengaruh Model Discovery Learning Berbantuan Media Lingkungan Alam Sekitar Terhadap Hasil Belajar IPA Siswa Kelas V Sekolah Dasar Gugus 5 Blahbatuh Tahun Ajaran 2016/2017".

\section{Metode}

Pelaksanaan penelitian dilakukan di SD Gugus 5 Blahbatuh, Kecamatan Blahbatuh, Kabupaten Gianyar. Jenis penelitian ini merupakan penelitian eksperimen semu mengguna-kan rancangan non equivalent control group design.Hal ini dikarenakan kemam-puan peneliti dalam mengamati perilaku siswa sangat terbatas terutama ketika siswa berada di luar sekolah (rumah). Pada dasarnya penelitian ini bertujuan untuk mengetahui perbedaan hasil belajar IPA antara kelompok siswa yang dibe-lajarkan menggunakan model discovery learning berbantuan media lingkungan alam sekitar dengan kelompok siswa yang dibelajarkan menggunakan pembelajaran konvensional pada siswa kelas V SD Gugus V Blahbatuh tahun 2016/2017.

Populasi dari penelitian ini adalah seluruh siswa kelas V di SD Gugus 5 Blahbatuh yang berjumlah 131 orang. Pengambilan sampel pada penelitian ini dilakukan dengan teknik random sampling. Teknik random sampling adalah teknik penentuan sampel secara acak (Sugiyono, 2014:118). Teknik random sampling yang dilakukan dalam penelitian ini yaitu dengan cara undian sehingga setiap SD mendapat peluang yang sama untuk menjadi sampel penelitian.

Dalam penelitian ini, yang dirandom adalah kelasnya tidak dilakukan pengacakan individu, karena tidak bisa mengubah kelas yang telah terbentuk sebelumnya. Kelas yang dipilih telah terbentuk tanpa campur tangan peneliti, kemungkinan pengaruh-pengaruh dari keadaan subjek mengenai dirinya dilibatkan dalam eksperimen dapat dikurangi sehingga penelitian ini benar-benar menggambarkan pengaruh per-lakuan yang diberikan.

Sampel tersebut selanjutnya diberikan pre test untuk meyakinkan bahwa kedua kelompok yang dipilih dengan random sampling setara. Nilai dari hasil pre test dianalisis dengan menggunakan uji-t. Sebelum uji kesetaraan menggunakan uji t, maka data hasil pre test diuji prasyarat yaitu uji normalitas dan homogenitasnya.

Berdasarkan perhitungan yang dilakukan, diperoleh rata-rata hasil pretest kelompok eksperimen $=$ 64,69 dan rata-rata hasil pretest kelompok kontrol $=60,50, t_{\text {hitung }}=1.570$, sedangkan $t_{\text {tabel }}=2.000$. Hal ini

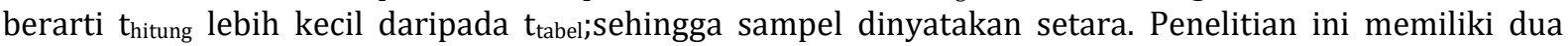
variabel, yaitu variabel bebas dan variabel terikat. Variabel bebas dalam penelitian ini adalah model discovery learning berbantuan media lingkungan alam sekitar yang diterapkan pada kelompok eksperimen dan pembelajaran konvensional yang diterapkan pada kelompok kontrol. Variabel terikat penelitian ini yaitu hasil belajar IPA.

Secara garis besar metode pengumpulan data dapat dibedakan menjadi 2 (dua) jenis, yaitu metode tes dan non- tes. Pengumpulan data dengan metode tes, dalam kaitannya dengan penelitian adalah cara memperoleh data dengan bentuk tugas yang harus dikerjakan oleh seorang atau kelompok orang yang dites (testee), dan dari tes dapat menghasilkan suatu skor (interval) ( Agung, 2012). Metode pengumpulan data pada penelitian ini yaitu menggunakan teknik tes. Sedangkan, metode non-tes adalah penilaian atau evaluasi hasil belajar peserta didik dilakukan dengan tanpa "menguji" peserta didik, melainkan dengan melakukan pengamatan secara sistematis. Metode non- tes pada umumnya memegang peranan yang penting dalam rangka mengevaluasi hasil belajar siswa dari ranah sikap dan keterampilan. 
Contoh non-tes seperti: metode observasi, metode Interview/Wawancara, dan metode kuesioner/Angket( Sudijono, 2015).

Berkaitan dengan hal tersebut, maka dalam penelitian ini metode pengumpulan data yang digunakan adalah metode tes. Tes hasil belajar IPA merupakan instrumen yang digunakan. Instrumen tersebut diuji terlebih dahulu sebelum digunakan. Kisi-kisi soal disusun terlebih dahulu, kemudian disusun soal dan dikonsultasikan dengan ahli, selanjutnya dilakukan uji validitas butir soal, reliabilitas, daya pembeda, dan tingkat kesukaran butir soal. Uji instrumen dilakukan dengan jumlah responden sebanyak 39 orang siswa. Dari 50 soal yang diujikan, diperoleh 30 soal yang dinyatakan layak untuk digunakan pada penelitian ini.

Tes yang digunakan pada penelitian ini adalah tes obyektif, hal itu dikarenakan untuk dapat mempermudah peneliti menilai jawaban dari tes yang sudah dikerjakan oleh siswa. Hasil tes dapat diolah dengan cepat dan mempunyai ketetapan hasil pemeriksaan tinggi. Pada tes obyektif, penskoran nilai yaitu siswa yang menjawab dengan benar $(\sqrt{ })$, maka setiap butir soal (item) akan diberikan skor 1 . Sedangkan bila siswa menjawab dengan salah (X), maka setiap butir soal (item) akan diberikan skor skor 0 (dimana pilihan jawaban siswa tersebut akan dicocokkan dengan kunci jawaban yang sudah ditentukan). Selanjutnya, skor benar yang diperoleh siswa dijumlahkan dan jumlah skor tersebut menjadi variabel dari hasil belajar ipa. Item tes pada soal obyektif disusun berdasarkan kisi-kisi soal yang sudah dirumuskan dan butir tes disusun oleh peneliti melalui bimbingan dosen. Namun, sebelum memberikan tes kepada siswa, maka dilakukan pengujian untuk menguji kelayakan instrumen. Menguji kelayakan tes atau instrumen tersebut agar dapat digunakan sebagai instrumen penelitian, maka harus dilakukan pengujian terlebih dahulu. Karena instrumen tersebut berupa pilihan ganda maka hal-hal yang perlu diuji validitas, daya beda, indeks kesukaran, dan reliabilitas.

Menurut Sudijono (2015:63) validitas adalah "salah satu ciri yang menandai tes hasil belajar yang baik". Uji validitas yang digunakan adalah uji validitas isi dan uji validitas butir. Sebuah tes dikatakan memiliki validitas isi apabila mengukur tujuan khusus tertentu yang sejajar dengan materi atau isi pelajaran yang diberikan ( Suharsimi 2013:82). Uji validitas isi dilakukan dengan cara menyesuaikan butir tes dengan indikator dan standar kompetensi.Berdasarkan analisis uji validitas butir tes hasil belajar IPA dengan menggunakan Microsoft Excel 2007 for Windows. dari 50 butir soal yang diujicobakan kepada 39 responden dengan taraf signifikansi $5 \%$ dengan $r_{\text {tabel }}=0.316$ diperoleh hasil 30 butir soal yang valid dan 20 butir soal yang tidak valid.

Supranata (2005:86) menyatakan bahwa "Reliabilitas atau keajegan suatu skor adalah hal yang sangat penting dalam menentukan apakah tes telah menyajikan pengukuran yang baik. Uji reliabilitas dilakukan terhadap butir soal yang valid saja, dengan demikian uji reliabilitas bisa dilakukan setelah dilakukan uji validitas.Berdasarkan hasil perhitungan terhadap 30 butir soal yang dinyatakan valid dan memiliki daya beda cukup sampai dengan baik sekali, maka diperoleh $r_{11}=0,89$. Berdasarkan hal tersebut, maka $r_{11}>0,70$ yang berarti tes objektif tipe pilihan ganda biasa pada penelitian ini tergolong reliable.

Menurut Suharsimi (2013:226) "daya pembeda soal adalah kemampuan sesuatu soal untuk membedakan antara siswa yang pandai (berkemampuan tinggi) dengan siswa yang bodoh (berkemampuan rendah)".Berdasarkan perhitungan daya pembeda dengan menggunakan Microsoft excel 2007, dari 30 butir tes yang telah dinyatakan valid 4 butir soal dengan kriteria cukup, 20 butir soal dalam kategori baik dan 6 butir soal dalam kategori baik sekali. Berdasarkan hal di atas, maka diketahui sebanyak 30 butir soal yang dapat dipergunakan sebagai instrumen penelitian.

Tingkat kesukaran merupakan salah satu karakteristik yang dapat menun-jukkan kualitas butir soal tersebut apakah tersebut mudah, sedang atau sukar (Suryanto, 2014:5.22). Bermutu tidaknya butir-butir item tes belajar pertama-tama dapat diketahui dari derajat kesukaran atau taraf kesulitan yang dimiliki oleh masing-masing butir item tersebut Sudijono, (2015:370).

Bilangan yang menunjukkan sukar dan mudahnya sesuatu soal disebut indeks kesukaran (difficulty index). Besarnya indeks kesukaran berkisar antara nilai 0,00 sampai dengan 1,00. Soal dengan indeks kesukaran 0,00 berarti butir soal tersebut terlalu sukar, sebaliknya indeks kesukaran soal mendekati 1,00 berarti soal tersebut terlalu mudah (Suharsimi,2013:223). Berdasarkan hasil analisis uji coba instrumen dan kriteria tingkat kesukaran, maka diketahui tingkat kesukaran perangkat tes adalah 0,53 . Sehingga indeks kesukaran perangkat tes termasuk dalam kriteria sedang.

Perhitungan tingkat kesukaran menggunakan Micsrosof Eksel 2007, dari dari 30 butir tes yang telah dinyatakan valid dalam uji validitas, dan reliabel terdapat 7 butir soal berkategori sukar, 15 butir soal berkategori sedang dan 8 butir soal berkategori mudah.

Data yang diperoleh dalam penelitian ini adalah datahasil belajar IPA yang berasal dari nilai post test kelompok eksperimen maupun kolompok kontrol. Kedua data tersebut kemudian dianalisis dengan menggunakan analisis statistik deskriptif untuk mendeskripsikan masing-masing data. 
Statistik deskriptif adalah statistik yang digunakan untuk menganalisis data dengan mendeskripsikan atau menggambarkan data yang telah terkumpul sebagaimana adanya tanpa bermaksud membuat kesimpulan yang berlaku untuk umum atau generalisasi (Sugiyono, 2012:147).

Data kuantitatif hasil penelitian dari data post test dideskripsikan melalui nilai tertinggi, nilai terendah, rata-rata ( mean), standar deviasi dan varian. Data tersebut disajikan dalam tabel distribusi frekuensi dan diagram batang. penyajian data yang digunakan, yaitu dalam bentuk tabel data bergolong dan histogram serta perhitungan rata-rata (mean), Untuk menyajikan data ke dalam tabel distribusi frekuensi dapat ditempuh langkah-langkah, yaitu 1) menghitung rentang $2 \leq \chi_{\text {tabel }}^{2}$ maka $\mathrm{H}_{0}$ diterima (gagal ditolak) dan $\mathrm{H}_{\mathrm{a}}$ ditolak yang berarti sebaran data berdistribusi normal, sedangkan jika $\chi_{\text {hitung }}^{2}>\chi_{\text {tabel }}^{2}$ maka $\mathrm{H}_{\mathrm{o}}$ ditolak dan $\mathrm{H}_{\mathrm{a}}$ diterima (gagal ditolak) yang berarti data tidak berdistribusi normal. Taraf signifikansinya adalah $5 \%$ dan derajat kebebasannya $(\mathrm{dk})=\mathrm{k}-1$. Selanjutnya data yang normal diuji homegenitas untuk memastikan sebaran data kedua kelompok homogen. Uji homogenitas dilakukan dengan menggunakan uji F. Kriteria pengujian jika $F_{\text {hitung }}<F_{\text {tabel }}$,maka data yang dianalisis homogen. Data yang telah memenuhi prasyarat uji analisis tersebut kemudian dilakukan uji hipotesis. Uji hipotesis yang digunakan dalam penelitian ini yaitu uji-t. Kriteria pengujian adalah $\mathrm{H}_{\mathrm{o}}$ ditolak jika $t_{\text {hitung }}>t_{\text {tabel }} . t_{\text {tabel }}$ didapat dari tabel distribusi t pada taraf signifikan ( $\alpha$ ) $5 \%$ dengan derajat kebebasan $\mathrm{dk}=\left(\mathrm{n}_{1}+\mathrm{n}_{2}-2\right)$ dan $\mathrm{H}_{\mathrm{a}}$ ditolak jika $t_{\text {hitung }}<t_{\text {tabel }}$.

Data yang telah diuji normalitas dan homogenitas selanjutnya dilakukan uji hipotesisis, adapun hipotesis yang diuji dalam penelitian ini yaitu Ho : Tidak terdapat perbedaan yang signifikan hasil belajar IPA antara kelompok siswa yang dibelajarkan melalui model discovery learning berbantuan media lingkungan alam sekitar dan kelompok siswa yang dibelajarkan melalui pembelajaran konvensional pada siswa kelas V SD Gugus 5 Blahbatuh Tahun Ajaran 2016/2017.

Data yang diperoleh sudah memenuhi prasyarat uji normalitas data dan uji homogenitas varians, maka analisis yang digunakan adalah statistik parametrik. Pada statistik parametrik, uji hipotesis menggunakan uji t test dengan bentuk rumus polled varian karenajumlah anggota sampel sama $n_{1} \neq n_{2}$ dan varian homogen.

Hasil t hitung kemudian disbanding-kan dengan $\mathrm{t}$ tabel pada Pada taraf signi-fikansi $5 \%$ dengan $\mathrm{dk}$ $=\mathrm{n}_{1}+\mathrm{n}_{2}-2$. Dengan kriteria jika harga $\mathrm{t}_{\text {hitung }}$ lebih kecil dari harga $\mathrm{t}_{\text {tabel, }}$, maka $\mathrm{H}_{\mathrm{o}}$ diterima dan $\mathrm{H}_{\mathrm{a}}$ ditolak, dan jika harga $t_{\text {hitung }}$ lebih besar dari harga $\mathrm{t}_{\text {tabel }}$ maka $\mathrm{H}_{\mathrm{o}}$ ditolak dan $\mathrm{H}_{\mathrm{a}}$ diterima

\section{Hasil dan Pembahasan}

Data hasil belajar IPA siswa kelas V SD Negeri 4 Pering sebagai kelompok eksperimen yang dibelajarkan melalui modeldiscovery learningberbantuan media audio visual menunjukkan nilai tertinggi yang dicapai siswa adalah 97 dan nilai terendah yang dicapai siswa adalah 57. Berdasarkan perhitungan diketahui rentangan 41, banyak kelas 6, dan panjang kelas 7 .

Tabel 1. Distribusi Frekuensi Bergolong Data HasilBelajar IPAKelompok Eksperimen

\begin{tabular}{|c|c|c|}
\hline Kelas & Nilai Tengah (X) & $\begin{array}{l}\text { Frekuensi } \\
\text { (f) }\end{array}$ \\
\hline $56-62$ & 59 & 4 \\
\hline 63- 69 & 66 & 3 \\
\hline $70-76$ & 73 & 4 \\
\hline $77-83$ & 80 & 4 \\
\hline $84-90$ & 87 & 12 \\
\hline $91-97$ & 94 & 5 \\
\hline JUMLAH & & 32 \\
\hline
\end{tabular}

Kelas V SD Negeri 2 Pering yang dibelajarkan melalui pembelajaran konvensional . Data hasil belajar IPA siswa Kelas V SD Negeri 2 Pering sebagai kelompok kontrol yang pembelajarannya melalui pembelajaran konvensional, menunjukkan bahwa nilai tertinggi yang dicapai siswa adalah 83 sedangkan nilai terendah yang dicapai siswa adalah 50.Data tersebut kemudian disajikan dalam bentuk tabel distribusi frekuensi.Hasil hitung menunjukkan bahwa panjang kelas tiap interval adalah 6. Setelah diketahui 
rentangan, banyak kelas yang dapat dibentuk, dan panjang kelas tiap interval maka data dapat disajikan pada tabel distribusi frekuensi bergolong sebagai berikut.

Tabel 2. Distribusi Frekuensi Bergolong Data Hasil Belajar IPA Kelompok Kontrol

\begin{tabular}{llll}
\hline No & Kelas Interval & Nilai Tengah $(\mathrm{X})$ & Frekuensi (f) \\
\hline 1 & $48-53$ & 50.5 & 3 \\
2 & $54-59$ & 56.5 & 2 \\
3 & $60-65$ & 62.5 & 2 \\
4 & $66-71$ & 68.5 & 3 \\
5 & $72-77$ & 74.5 & 16 \\
6 & $78-83$ & 80.5 & 4 \\
JUMLAH & & 30 \\
\hline
\end{tabular}

Tabel 3. Hasil Analisis Data Hasil Belajar IPA Kelompok Eksperimen dan Kelompok Kontrol

\begin{tabular}{lll}
\hline Hasil Analisis & Kelompok Eksperimen & Kelompok Kontrol \\
\hline Mean & 80,00 & 70,30 \\
Varians & 132,77 & 82,30 \\
Standar Deviasi & 11.52 & 9,07 \\
Nilai minimum & 57 & 50 \\
Nilai & 97 & 83 \\
maksimum & & \\
\hline
\end{tabular}

Berdasarkan tabel 4.3 nilai mean atau rata-rata hasil belajar IPA kelompok eksperimen melalui model discovery learning berbantuan media lingkungan alam sekitar, yaitu $\bar{X}=80,00$ dengan varians yaitu $\mathrm{S}^{2}=$ 132,77 dan standar deviasi yaitu $S=11,52$, nilai maksimum $=97$, nilai minimum 57 . Rata-rata hasil belajar IPA tersebut kemudian konversikan ke dalam tabel PAP skala lima berada pada kategori tinggi. Sedangkan nilai mean atau rata-rata hasil belajar ipa siswa kelompok kontrol yang dibelajarkan melalui pembelajaran konvensional, yaitu $\bar{X}=70,30$ dengan varians yaitu $S^{2}=82,30$ dan standar deviasi yaitu $S=9$, 07. Kemudian rata-rata hasil belajar IPA kelompok kontrol dikonversikan ke dalam tabel PAP skala lima, sehingga dapat diketahui bahwa hasil belajar IPA kelompok kontrol berada pada kategori sedang. Berdasarkan analisis data tersebut diketahui bahwa kelompok eksperimen memiliki hasil belajar IPA yang lebih tinggi dibandingkan kelompok kontrol.

Pengujian asumsi dilakukan sebelum pengujian hipotesis adalah uji prasyarat analisis yaitu uji normalitas data dan uji homogenitas variansPengujian ini bertujuan untuk mengetahui sebaran data dari kedua kelompok berdistribusi normal. Uji normalitas dilakukan dengan Chi Kuadrat pada taraf signifikansi $5 \%$ dengan derajat kebebasan (dk) n-1. Kriteria pengujian pada uji normalitas adalah jika $\mathrm{x}^{2}$ hitung $<\mathrm{x}^{2}$ tabel maka sebaran data kedua kelompok berdistribusi normal.

Berdasarkan hasil uji normalitas kelompok eksperimen, diperoleh Chi Kuadrat hitung $\left(\mathrm{x}^{2}\right.$ hitung $=$ 6 ,68) kemudian nilai tersebut dibandingkan dengan Chi Kuadrat tabel $\left(\mathrm{x}^{2}\right.$ tabel $\left.=11,07\right)$. Hal ini menunjukkan bahwa $\mathrm{x}^{2}$ hitung $<\mathrm{x}^{2}$ tabel berarti data hasil belajar IPA kelompok eksperimen berdistribusi normal.

Selanjutnya hasil uji normalitas kelompok kontrol, diperoleh Chi Kuadrat hitung $\left(\mathrm{x}^{2}\right.$ hitung $\left.=8,18\right)$ kemudian nilai tersebut dibandingkan dengan Chi Kuadrat tabel $\left(\mathrm{x}^{2}{ }_{\text {tabel }}=11,07\right)$. Hal ini menunjukkan bahwa $\mathrm{x}^{2}$ hitung $<\mathrm{x}^{2}$ tabel berarti data hasil hasil belajar IPA kelompok kontrol berdistribusi normal.

Tabel 4 . PAP Skala Lima Kelompok Eksperimen

\begin{tabular}{cl}
\hline Persentase & Tingkat Kemampuan \\
\hline $90-100$ & Sangat tinggi \\
$80-89$ & Tinggi \\
$65-79$ & Sedang \\
$55-64$ & Rendah \\
$0-54$ & Sangat rendah \\
\hline
\end{tabular}


Data hasil belajar IPA pada kelompok kontrol diperoleh melalui post-test terhadap 30 orang siswa menunjukkan bahwa skor tertinggi yang diperoleh siswa adalah 83,dan skor teren-dah adalah 50 . Berdasarkan perhitungan diketahui rentangan 34, banyak kelas 6, dan pan-jang kelas 5.

Tabel 5. PAP Skala Lima Kelompok Eksperimen

\begin{tabular}{cl}
\hline Persentase & Tingkat Kemampuan \\
\hline $90-100$ & Sangat tinggi \\
$80-89$ & Tinggi \\
$65-79$ & Sedang \\
$55-64$ & Rendah \\
$0-54$ & Sangat rendah \\
\hline
\end{tabular}

Berdasarkan data tersebut kemudian dikonversikan pada tabel PAP skala Lima sehingga dapat diketahui hasil belajar IPA siswa kelompok control pada kategori cukup baik.Data yang diperoleh kemudian dianalisis dengan uji-t. Namun, sebe-lumnya perlu diuji prasyarat analisis dengan uji normalitas dan homogenitas. Berdasarkan hasil perhitungan uji normalitas dengan menggunakan tumus Chi-kuadrat, diperoleh bahwa data kelompok eksperimen dan kelompok kontrol berdistribusi normal. Uji homogenitas terhadap varians antar kelompok eksperimen dan kontrol meng-gunakan uji-F, diperoleh bahwa varian data hasil belajar IPA kelompok ekspe-rimen dan kelompok kontrol adalah homo-gen.Hasil dari uji prasyarat analisis data telah diperoleh, dilanjutkan dengan analisis uji-t dengan rumus polled varians. Rangkuman hasil perhitungan uji- $\mathrm{t}$ antara kelompok eksperimen dan kelompok control disajikan pada tabel 3.

Tabel 6. Hasil Uji-t

\begin{tabular}{lll}
\hline & Kelompok Ekperimen & Kelompok Kontrol \\
\hline $\mathrm{N}$ & 32 & 30 \\
$\mathrm{X}$ & 80.00 & 70.30 \\
$\mathrm{~S}^{2}$ & 132.77 & 82.30 \\
$\mathrm{~T}_{\text {hitung }}$ & 3.666 & \\
$\mathrm{~F}_{\text {tabel }}$ & 2.000 & \\
\hline
\end{tabular}

Berdasarkan nilai $t_{\text {hitung }}>t_{\text {tabel }}$ yaitu 3.666> 2,000 sehingga $H_{0}$ ditolak yang disimpulkan bahwa terdapat perbedaan yang signifikan hasil belajar IPA antara siswa kelas V di SD N4Pering yang me-ngikuti pembelajaran menggunakan model Discovery Learning Berbantuan Media Lingkungan Alam Sekitar dan siswa kelas V di SD N 2 Peringyang mengikuti pem-belajaran konvensional. Adapun perbe-daan yang signifikan menunjukkan bahwa penerapan model Discovery Learning Berbantuan Media Lingkungan Alam Sekitar berpengaruh terhadap hasil belajar IPA.

Sebelum dilakukan uji hipotesis dengan menggunakan uji-t, terlebih dahulu dila-kukan uji prasyarat yang meliputi uji normalitas sebaran data dan uji homo-genitas varians.Berdasarkan tabel analisis tersebut, $t_{\text {hitung }}>t_{\text {tabel }}$ yaitu 3,666 $>2,000$ sehingga $H_{o}$ ditolak yang disimpulkan bah-wa terdapat perbedaan yang signifikan hasil belajar IPA antara siswa kelas V di SDN 4 Pering yang mengikuti pembelajaran menggunakan model Discovery Learning Berbantuan Media Lingkungan Alam Sekitar dan siswa kelas V di SD N 2 Pering yang mengikuti pembelajaran konvensional

Dari perolehan hasil belajar IPA pada kedua kelompok tersebut, dapat diketahui bahwa kedua kelompok yang awalnya memiliki kemampuan yang setara, kemu-dian setelah diberikan perlakuan pada kelompok eksperimen dengan model Discovery Learning Berbantuan Media Lingkungan Alam Sekitarmaka perolehan nilai hasil belajar IPA mengalami per-bedaan. Hasil belajar IPA siswa pada kelompok eksperimen lebih baik apabila dibandingkan dengan hasil belajar IPA siswa pada kelompok kontrol.

Perbedaan yang signifikan hasil belajar IPA antara kelompok eksperimen dengan kelompok kontrol karena pada kelompok eksperimen diberikan perlakuan sedang-kan kelompok kontrol tidak diberikan perlakuan pada saat pembelajaran. Kelompok eksperimen diberikan perlakuan berupa model model Discovery Learning Berbantuan Media Lingkungan Alam Sekitarmemiliki nilai rata-rata lebih tinggi dibandingkan dengan kelompok kontrol yang menerapkan pembelajaran konvensional. Hal ini disebabkan karena modelDiscovery Learning Berbantuan Media Lingkungan Alam Sekitardapat membuat 
siswa menjadi lebih giat dalam belajar, membuat siswa aktif, termotivasi, dan mampu berinteraksi dalam pembelajaran. Selama kegiatan pembe-lajaran siswa lebih aktif karena kegiatan pembelajaran menggunakan model Discovery Learning Berbantuan Media Lingkungan Alam Sekitar belajar yang memberikan kesempatan yang sama kepada setiap siswa.

Berbeda dengan pembelajaran konvensional yang terjadi selama pembelajaran IPA di kelompok kontrol. Kegiatan pembelajaran dilakukan dengan caramenyampaikan sejumlah materi kepada siswa yang diselingi dengan sedikit Tanya jawab kemudian diikuti dengan pemberian tugas secara individu. Dengan pembelajaran seperti ini siswa tidak mempunyai kesempatan untuk mengembangkan kemampuan berpikir dankesempatan menyampaikan pendapatnya untuk bekerjasama dengan teman sebaya, sehingga siswa akan merasa bosan saat pembelajaran berlangsung.

\section{Simpulan dan Saran}

Berdasarkan hasil analisis data hasil belajar IPA pada kelompok eksperimen yang berjumlah 32 orang siswa dengan nilai rata-rata yaitu $\bar{X}=80,00$. Bila dikonversikan dalam PAP skala lima nilai rata-rata siswa pada kelompok eksperimen berada pada kategori tinggi. Hasil analisis data hasil belajar IPA pada kelompok kontrol yang berjumlah 30 orang siswa dengan nilai rata-rata yaitu $\bar{X}=70,30$. Bila dikonversikan dalam PAP skala lima nilai rata-rata siswa pada kelompok eksperimen berada pada kategori sedang. Dan hasil analisis data post-test menunjukkan rerata hasil belajar kelompok ekperimen lebih tinggi daripada kelompok kontrol 80,00 > 70,30. Berdasarkan hasil analisis uji-t diperoleh $t_{\text {hitung }}=$ 3,666 dengan taraf signifikansi $5 \%$ dan $d k=60$ diperoleh harga $t_{\text {tabel }}=2.000$ dapat disimpulkan bahwa Ha diterima dan Ho ditolak. Berdasarkan hasil perhitungan uji-t menunjukan bahwa terdapat perbedaan yang signifikan hasil belajar IPA antara kelompok siswa yang dibelajarkan melalui Model Discovery Learning Berbantuan Media Lingkungan Alam Sekitar dan kelompok siswa yang dibelajarkan melalui pembelajaran konvensional. Berdasarkan perbedaan nilai rata-rata kedua kelompok dan hasil uji hipotesis, maka dapat disimpulkan bahwa penerapan model discovery learning berbantuan media lingkungan alam sekitar berpengaruh terhadap hasil belajar IPA pada siswa kelas V SD Gugus 5 Blahbatuh Tahun Ajaran 2016/2017.

Berdasarkan hasil penelitian ini, adapun saran yang dapat disampaikan yaitu sebagai berikut. Kepada Sekolah, setingginya mempertimbangkan peman-faatan lingkungan sebagai media yang menunjang pembelajaran. Serta guru dapat membelajarkan siswa dengan model-model yang bervariasi yang disesuaikan dengan karakteristik model tersebut serta mata pelajarannya.Kepada Guru, Guru hendaknya menjadikan hasil penelitian ini sebagai bahan pertimbangan dalam menyusun perencanaan pembela-jaran serta sebagai alternatif dalam penerapan model pembelajaran.. Kepada Siswa, dengan diterapkannya model discovery learning berbantuan media lingkungan alam sekitar, pembelajaran IPA siswa lebih antusias untuk belajar dan mampu mengembangkan kreativitasnya dalam mengikuti pembelajaran serta mampu membangun pengetahuannya sendiri melalui pengalaman belajar penemuanuntuk meningkatkan hasil belajar siswa. Dengan demikian, siswa mampu mengaplikasikan apa yang telah diperoleh dalam pembelajaran yang nan-tinya akan diterapkan dalam kehidupan sehari-hari.

\section{Daftar Rujukan}

Agung, A. A. Gede. 2014. Metodologi Penelitian Pendidikan. Yogyakarta: Aditya Media Publishing.

Dewantara, D. (2014). Penerapan Model Pembelajaran Problem Based Learning Untuk Meningkatkan Aktivitas Dan Hasil Belajar Siswa Pada Pelajaran IPA (Studi Pada Siswa Kelas V SDN Pengambangan 6 Banjarmasin). Jurnal Paradigma Volume 11 Nomor 2 Juli 2016, 41 - 44.

Fitri, Mariza dan Derlina. 2015. Pengaruh Model Pembelajaran Discovery Learning Terhadap Hasil Belajar Siswa Pada Materi Pokok Suhu Dan Kalor. Tersedia pada http://jurnal.unimed.ac.id/2012/index.php/inpafi/article/view/5130/8113.

Indah, N. (2015). Meningkatkan Prestasi Belajar IPA Materi Pokok Sumber Energi Gerak Melalui Penerapan Model Pembelajaran Problem Based Learning (PBL) Pada Siswa Kelas I.A SD Negeri 9 Kabangka Tahun Ajaran 2014/2015. 50 - 55

Koyan, I Wayan. 2012. Statistik Pendidikan. Singaraja: Undiksha.

Kosasih. 2014. Strategi Belajar Dan Pembelajaran. Bandung: Yrama Widya. 
Kurniasih, Imas \& Berlin Sani. 2015. Ragam Pengembangan Model Pembelajaran Untuk Meningkatkan Profesional Guru. Jakarta: Kata Pena.

Kusumaningrum, Putu Citra Arni. 2014. "Pengaruh Model Pembelajaran Kooperatif Tipe Team Games Tournament (TGT) Terhadap Hasil Belajar IPA Pada Siswa Kelas V Gugus XV Kecamatan Buleleng Tahun Ajaran 2013/2014". e-Journal Mimbar PGSD Universitas Pendidikan Ganesha Jurusan PGSD, Vol 2, No 1.

Putrayasa, I Made, H. Syahruddin, I Gede Margunayasa. 2014. "Pengaruh Model Pembelajaran Discovery Learning Dan Minat Belajar Terhadap Hasil Belajar IPA Siswa". Jurnal Mimbar PGSD Universitas Pendidikan Ganesha. Vol. 2, No. 1.

Rahmasari, R. (2016). Penerapan Model Pembelajaran Problem Based Learning Untuk Meningkatkan Hasil Belajar IPA Kelas IV SD. Jurnal Pendidikan Guru Sekolah Dasar Edisi 36 Tahun ke 5 2016, 3456 3465.

Sanaky. 2011. Media Pembelajaran. Yogyakarta: Kaukaba Dipantara.

Sanjaya, Wina. 2009. Strategi Pembelajaran Berorientasi Standar Proses Pendidikan. Jakarta: Prenada Media Group.

Setyosari, Punaji. 2015. Metode Penelitian Pendidikan \& Pengembangan. Jakarta: Kencana.

Sudijono, Anas. 2013. Pengantar Evaluasi Pendidikan. Jakarta: PT Raja Grafindo Persada.

Sugiyono. 2012. Metode Penelitian Pendidikan Pendekatan Kuantitatif, Kualitatif, dan R\&D. Bandung: ALFABETA.

Suharsimi. 2013. Dasar-dasar Evaluasi Pendidikan. Jakarta: Bumi Aksara.

Supriyanto, Bambang. 2014. "Penerapan Discovery Learninguntuk Meningkatkan Hasil Belajar Siswa Kelas VI B Mata Pelajaran Matematika Pokok Bahasan Keliling Dan Luas Lingkarandi SDN Tanggul Wetan 02 Kecamatan Tanggul Kabupaten Jember". Pancaran Pendidikan. Vol. 3, No. 2.

Susanto, Ahmad. 2014. Teori Belajar Dan Pembelajaran Di Sekolah Dasar. Jakarta: Kencana.

Suwandi, Y. (2015). Peningkatan Hasil Belajar IPA Tentang Ekosistem Melalui Metode Problem Based Learning Pada Siswa Kelas V Sekolah Dasar Kabupaten Tana Tidung. Jurnal Pendidikan Dasar Volume 6 Edisis 1 mei 2015, 93 - 102. 